\title{
Urgences
}

\section{Poèmes sans titre}

\section{Lise Lessard}

Numéro 2, 3e trimestre 1981

URI : https://id.erudit.org/iderudit/025030ar

DOI : https://doi.org/10.7202/025030ar

Aller au sommaire du numéro

Éditeur(s)

Urgences

ISSN

0226-9554 (imprimé)

1927-3924 (numérique)

Découvrir la revue

Citer ce document

Lessard, L. (1981). Poèmes sans titre. Urgences, (2), 61-65.

https://doi.org/10.7202/025030ar

Ce document est protégé par la loi sur le droit d'auteur. L'utilisation des services d'Érudit (y compris la reproduction) est assujettie à sa politique d'utilisation que vous pouvez consulter en ligne.

https://apropos.erudit.org/fr/usagers/politique-dutilisation/
Cet article est diffusé et préservé par Érudit.

Érudit est un consortium interuniversitaire sans but lucratif composé de l'Université de Montréal, l'Université Laval et l'Université du Québec à Montréal. Il a pour mission la promotion et la valorisation de la recherche. https://www.erudit.org/fr/ 
LISE LESSARD

\section{Poèmes sans titre}


Il avait l'âme d'un oiseau

et gardait dans sa poche

un peu d'obscurité

s'y couchait

comme une vague

dans un vase

Et sur sa poitrine de sable

l'aigle très doux

ouvrait des griffres pleines de paille

dans les herbes de cet été

un enfant jouait de la flûte

et une abeille des cymbales

Il avait l'âme d'un oiseau

et dans le dos une vallée d'argile

où glissaient des filets d'eau très minces

et qui sentaient la coriandre

et l'ananas 
Nous n'irons plus pêcher les éperlans disait la fille

mais qui regardera

et verra s'avancer

vers les cordes à danser de son rire

une fillette en robe courte

qui écrira les sons qui le suivent de près

aux transparents de ses cahiers

qui s'esquintera les yeux

aux montures de ses lunettes

avant de grimper l'escalier

qui éteindra le dernier bras

posé comme une rampe

sur une lampe

Il m'arrache et me découd ma blouse d'amour disait la fille

j'irai sur la route immobile

le sable entrera dans mes souliers 


\section{$\mathrm{Tu}$ ris}

comme ta barque ira sur l'eau

dans l'eau de tes yeux d'eau

à marée haute

Ton rire brille comme une toile d'araignée

dans un champ d'épervières oranges

quand le jour s'est assis

au milieu du soleil

comme au lac de mon dos

tu t'en viens boire

$\mathrm{Tu}$ remplis de framboises

le grand bol de l'été

Tu m'offres

une pierre d'eau infinie

enveloppée de boules de lumière froissée

toute la soie du ciel

aux encoignures mauves

aux arêtes rosées

Dans le vase de l'eau

chaque montagne est un iris coupé

dans les grandes herbes des carouges

Quand les cils du soleil clignent

sur les pétales d'eau de tes yeux

chaque morceau de ta bouche luit

on dirait de la berle douce

sous la lune 
Les jours s'ouvraient comme des oeufs le coeur luisant de transparence

le grand geste de la mer

la courbe de son bras

sur la taille de la terre

ramenée sous son ventre

et des oiseaux passaient toujours

comme devraient passer les anges

Descendions un sentier

poches pleines d'oranges

pour aller regarder

la mer monter

le bel amour

que j'ai planté

poignée de seigle

écrasé

sous la lourde lumière

Les jours se fermaient comme les portes des épiceries quand les épiciers s'en vont boire

ils montaient vers la grande armoire sur une chaise à la renverse ils s'endormaient brillaient sur la chemise noire toutes les gouttes des bouteilles qu'ils n'avaient pas fini de boire

Ils vont s'ouvrir comme des oeufs le coeur luisant de transparence des oiseaux passeront toujours comme devraient passer les anges 